\title{
Astolphe de Custine and the querelle d'Olivier: Gossip in Restoration High Society
}

Abstract. This article explores the relationship between gossip and sexuality in early nineteenth-century France, through consideration of the biography of Astolphe de Custine and the novels of the so-called querelle d'Olivier: Madame de Duras's Olivier, ou le secret (c. 1821); Henri de Latouche's Olivier (1826); and Stendhal's Armance (1827). These three romans à clé were inspired, at least in part, by two events in Custine's life: his breaking of an engagement to Mme de Duras's daughter Clara in 1818, and his 'outing' as a homosexual in 1824, when he was brutally beaten for having propositioned a guardsman. Both events occasioned outbursts of gossip within Restoration high society, and this article considers the Olivier novels as part of, and as responses to, that gossip: though motivated by personal or political animosity, the novels equally frame an ambivalent critique of the process whereby gossip enforces social norms, notably in matters of sexuality. The two later novels, composed in the wake of Custine's humiliation of 1824 , even seem to anticipate the structure of the modern closet; but the article concludes by underlining both the historical specificity and the broad metaphorical valence of the texts' evocation of sexual secrets. 


\section{Astolphe de Custine and the querelle d'Olivier: Gossip in Restoration High Society}

In memoirs published in 1825, Mme de Genlis dwells for some pages on her fondness for a young aristocrat, Astolphe, marquis de Custine. Genlis notes a couple of occasions when she had even attempted to act as matchmaker for the young marquis, before his marriage in 1821 - a match finally brokered by his mother, but which Mme de Genlis graciously celebrates all the same. Whether as the result of delays in publication, or, as is conceivable, as a consequence of the elderly author's naivety, these passages doubtless struck Mme de Genlis's earliest readers in Parisian high society as rather unfortunate. One passage in particular must have caused mean-spirited mirth when those few pages were first cut: a quotation Mme de Genlis gives from a poem inscribed by Astolphe in a scrap book he presented to her some years before. The poem, a paean to friendship, contrasts that peaceful affect with the frenetic passion of love:

L'amour affronte la tempête,

Et l'insensé, dans son orgueil,

Malgré l'orage qui s’apprête,

Veut encore braver l'écueil. ${ }^{1}$

The poem is trite, and Custine, always chary of sharing his poetic efforts with the public, seems unlikely to have consented to its inclusion. Yet beyond its aesthetic shortcomings, this stanza's appearance in 1825 must have been rendered particularly embarrassing in light of the events of 28 October of the previous year. For on that evening, something that in French can be called 'l'amour' had indeed persuaded Custine to 'ignore the gathering storm' and 'brave ruin': amid historic downpours and catastrophic flooding, Custine set out from Saint-Denis to Épinay-sur-Seine, alone and on foot, expecting to meet a guardsman for an amorous tryst. He was met by not one, but several guardsmen, assembled there to deliver a correctional beating 
to the man who had dared to proposition one of their brothers-in-arms. By the time he was found, half naked in the dirt by the waterlogged road, his reputation in society was as good as destroyed. $^{2}$

This moment in Mme de Genlis's memoirs reveals the unpredictable contextual effects of one person's making public another's private communication, and which may arise even in the absence of any malicious intent. The embedding of Custine's 'work' within that of his old friend produces an intricate generic tangle: a literary text destined for purely private consumption - assuming a text so destined may be called 'literary' - is involuntarily published within a non- or para-literary text, the memoir, whose claim to public interest lies at least in part in its promise to divulge private information not normally part of the literary sphere. Both texts allude to the private life of Astolphe de Custine; yet while neither refers to what was by 1825 the best-known detail of that private life (the scandal of the previous year), neither could by the time of their publication be understood to refer to anything else. They thus found themselves drawn into the maelstrom of gossip surrounding Custine after his disgrace, gossip which found its finest expression in a third literary genre: the roman à clé, no fewer than three of which attach to - though of course, none actually uses - Custine's name. In this article, I will consider what one critic calls 'this complex and difficult nexus of texts, events, and silences' as exemplary of the relationship between literature, gossip, and sexuality in the early nineteenth century. ${ }^{3}$ I will suggest that these romans à clé - Madame de Duras's unpublished Olivier, ou le secret (c. 1821); Heni de Latouche's imitation, Olivier (1826); and Stendhal's Armance (1827) - have a double status, appearing at once as depictions (even, conceivably, denunciations) of gossip, but also irremediably as acts of gossip in their own right; indeed, the novels both exemplify and critique the role of gossip in 'maintain[ing]' - often coercively - 'the unity, morals and values of social groups' ${ }^{4}$ I will consider how the oppressive power of gossip, and its use in these novels to regulate sexual 
behaviour, appears to evoke a structure uncannily like the modern closet; yet I shall also suggest the historical and political importance of resisting the temptation to identify the male protagonists as 'homosexuals', and of allowing the novels' idiosyncratic ideas about sexuality and gossip to speak.

\section{The querelle d'Olivier}

The scandal of 1824 was not the first time that Astolphe de Custine had set tongues wagging. He had already dismayed le tout Paris in 1818 , by precipitously breaking off his engagement to Clara, daughter of the moderate royalist salonnière Claire de Kersaint, duchesse de Duras. ${ }^{5}$ His reasons for doing so are unclear; in a letter of July 1818 to his friend Rahel Varnhagen von Ense, he merely offers a fanciful depiction of a Mme de Duras bent for her own strange ends upon convincing a naive young man that he is in love with her daughter, when in fact he is only fond of her. He also recounts the conversation with Mme de Duras during which he ended the betrothal:

Je l'ai engagée par la générosité de son caractère [...] à ne faire aucun éclat, elle a donné je ne sais quelle raison à son mari pour retirer sans blesser son orgueil la demande que je lui avais faite... ${ }^{6}$

That 'je ne sais quelle raison' is to be compared with a diary note made by Custine's sometime close friend Édouard de La Grange the following month: 'Courchamps me dit que l'on lui a dit que M. de Duras n'avait pas donné sa fille à M. de Custine pour la raison qu'on lui avait dit qu'il était impuissant. ${ }^{, 7}$ This, it seems, was the reason devised by the Duras family, and that soon became widely known within high society: they had dissolved the engagement, having learned that Custine was impotent. And while the disreputable Courchamps was doubtless a significant contributor to the spread of this rumour, La Grange's 
diary note probably reflects a more widespread awareness of and interest in Custine's sexual peculiarities after the 1818 incident.

The rumours about Custine must indeed have been irresistible to high-society gossips, whom the memoirs and journals of the era reveal to have been oddly preoccupied by the general topic of impotence. While we might detect paranoia in Stendhal's assertion that, following an ill-fated amorous episode with an indiscreet lady, 'je passai pour babilan [i.e. impotent] dans le monde', ${ }^{8}$ other men certainly did acquire this 'réputation' through gossip. Writing of the cardinal-duc de Rohan-Chabot, the duchesse de Maillé observed suggestively in her journal that 'la faiblesse de sa santé contribuait merveilleusement à la pureté de ses mœurs', adding that he was 'presque un homme'; while her friend the comtesse de Boigne noted that 'les mauvaises langues prétendaient que le célibat n'imposait pas trop de gêne à monsieur de Rohan'. ${ }^{9}$ The impotence of the childless Louis XVIII himself, meanwhile, was considered an established fact and openly alluded to in society. ${ }^{10}$ These rumours, it should be noted, referred not to some temporary medical condition or embarrassing sexual encounter, but rather to a supposedly more fundamental truth about the impugned individual's character; impotence in the early nineteenth-century was, we might say, a status, almost a sexual identity in its own right, analogous to modern-day notions of homosexuality and thus an ideal substrate for the secret-revealing discourse that is gossip. ${ }^{11}$

Whoever was most active in disseminating such gossip about Custine, there is little doubt as to what preserved the rumour for posterity: Mme de Duras's decision to compose and read aloud to her circle Olivier, ou le secret, a novel that Custine's biographer calls her 'basse vengeance', and which she probably began when Custine finally married in May 1821. ${ }^{12}$ Though the titular secret is never divulged, it seems that Duras did mention impotence to her intimates; indeed, the novel's subject became more widely known than the novel itself, a 'gageure en famille', in the duchesse de Maillé's words, whose existence was 
confined to the semi-private sphere of the Duras salon. ${ }^{13}$ There was also little doubt that Olivier was a roman à clé based on the rupture between Mlle de Duras and Custine, and again, the limited exposure of the actual text made this perception more easily sustainable the novel's plot corresponds less well to the events of 1818 than most people probably assumed. Yet just as Mme de Genlis's publication of Custine's poem in her memoirs must have produced unforeseen effects following the scandal of 1824, so Duras's story was transformed and re-energized by that same event. This unexpected reconfiguration prompted the two subsequent novels in what is sometimes called la querelle d'Olivier: Latouche's Olivier and Stendhal's Armance. Both relate the story of an eligible young nobleman Latouche's Olivier and Stendhal's Octave - who proves incomprehensibly reluctant to marry an otherwise well-suited heroine (Émilie and the eponymous Armance respectively). Both heroes, it transpires, are prevented from marrying by an unspeakable secret; both finally yield, only to disappear the morning after the marriage - Olivier to enter a monastery (thus annulling the marriage), Octave to die by Byronic pseudo-suicide en route to the Greek war.

Neither Latouche nor Stendhal had heard the original Olivier since both were politically and socially well outside the Duras circle - a fact to which Stendhal makes witty reference in his 'Avant-propos':

On fait à Londres des romans très piquants [...] qui ont besoin d'une clé. Ce sont des caricatures fort plaisantes contre des personnes que les hasards de la naissance ou de la fortune ont placées dans une position qu'on envie.

Voilà un genre de mérite littéraire dont nous ne voulons point. L'auteur n'est pas entré, depuis 1814, au premier étage du palais des Tuileries ; il a tant d'orgueil, qu'il ne connaît pas même de nom les personnes qui se font sans doute remarquer dans un certain monde. ${ }^{14}$ 
There is, of course, no clearer indication of one's intention to write a roman à clé than a preface claiming the opposite, and Stendhal's exclusion from Court since the beginning of the Restoration is, as he well knows, more realistically evidence of the malice he harbours towards the Tuileries elites (the duc de Duras had indeed served at Court as First Gentleman of the Chamber) than proof of his innocent ignorance. It is, then, perfectly possible to see in this roman à clé, and its predecessor, mere gossip - though gossip whose victim was no longer Custine alone, but also Mme de Duras herself. At least part of Latouche's motivation resided in the ungentlemanly urge to force Mme de Duras to 'get her name in the papers' - as indeed she only technically avoided doing, formally denying in three newspapers that the pseudo-Olivier was by 'l'auteur d'Édouard', a periphrasis that was nevertheless transparent to those who mattered, and which thus drew her further into the public sphere her class and sex demanded she avoid. ${ }^{15}$ Notwithstanding this repudiation, moreover, a note in $L a$ Quotidienne the same week reminded Mme de Duras of her feminine duty of modesty, deploring her tasteless choice of subject and lamenting that 'les indiscrétions de l'amitié' had caused it to be widely known. ${ }^{16}$ In his preface, Stendhal allows himself a wicked nod to this humiliating contretemps and the haughty value system it flouted, by claiming that his novel is the work of a society lady 'qui se croirait vieillie de dix ans si l'on savait son nom' (49).

Feminist critics have explored the misogyny at work in Latouche's plagiaristic appropriation of Mme de Duras's original idea, and even in Stendhal's reworking of it; and sure enough, the violation of feminine privacy is a structural principle of the 1826 Olivier. ${ }^{17}$ The novel flaunts its own hypocrisy when, in a preface, the narrator presents the following pages as excerpted from the late heroine Émilie's private papers, published here reluctantly and only to correct errant rumour - a self-conscious allusion to the very real literary violation that gave the novel life. ${ }^{18}$ Yet this ironic assertion of a duty of publicity had, at least conceivably, political resonances that make Latouche's novel something more than a 
misogynist canard: by its very existence, Olivier hints darkly that while the corridors of power (fancifully equated in the literary imagination with the aristocratic salon) ${ }^{19}$ may be exclusive, they can never again be hermetic. An aristocratic lady novelist may not therefore presume to treat titillating subjects - 'd'ailleurs un tel sujet !.....' gasps Stendhal (49) - with impunity simply because she does so in semi-private surroundings. Stendhal's preface makes this political animus even more obvious. There, the Court elite are pointedly described as 'privilégiés' (47), that watchword of the Revolutionary cahiers de doléance; and though the Stendhal of the preface ironically claims not to know so much as the names of these lofty individuals, the very existence of this novel and its predecessor reveals that neither their identities nor their activities constitute privileged information.

Both novels, finally, knowingly exploit Duras's original 'secret' to stigmatize, in the wake of the 1824 scandal, something that we would now call homosexuality. Custine's humiliation remained central to the later works: indeed, of all three novels, it is paradoxically the subtlest - Armance, whose author changed his hero's name from Olivier to Octave precisely in order to be less obvious - that alludes to Custine most obviously. It does so in an episode in which Octave is inexplicably beaten by a group of guardsmen; in the character of Octave's bachelor uncle, the commandeur de Soubiran, who closely resembles Custine's own uncle Elzéar de Sabran; and in Stendhal's tasteless decision to name the twelfth-century ancestor whom Octave worships with sterile devotion 'Enguerrand' - the name of Custine's only child, who had died at the age of three in January 1826 . On the face of it, the novels treat Custine as vindictively as they did Mme de Duras: though Charles X himself saw to it that the 1824 affair was silenced, causing both Custine's and the guardsmen's depositions to be destroyed, ${ }^{20}$ and while newspaper reportage was confined to a terse notice interpretable only by those already in the know, the Olivier novels snidely returned the matter to the public sphere and thus contested the aristocratic privilege of secrecy. ${ }^{21}$ Yet it is precisely in their 
exploration of the sexual secrets of their male protagonists, and of the social scrutiny to which they are subjected, that the novels acquire a kind of double status. Gossipy as they most certainly are, all three Olivier novels nevertheless offer important insights into the interrelation of sexuality and gossip under the Restoration and beyond.

\section{Gossip in the Olivier novels}

Theorists differ as to whether or not gossip must name its target. While Nicholas Hammond identifies a range of authorities who maintain that in gossip, 'the victim is clearly specified', Max Gluckman follows his anthropologist predecessor Melville Herskovits in suggesting that gossip will often be 'oblique' in this respect, expressing itself 'warily' to avoid recrimination. ${ }^{22}$ The Olivier novels are at the very least gossip of the latter sort, proceeding by strategic hints rather than by direct accusation. Yet even then, their pointed refusal to name names perhaps makes them a limit-case of gossip: do they not, we might ask, merely allude to gossip - that is, to other people's gossip? To answer this question, let us return to La Grange's formulation of the Custine-Duras episode of 1818: 'Courchamps me dit que l'on lui a dit que M. de Duras n'avait pas donné sa fille à M. de Custine pour la raison qu'on lui avait dit qu'il était impuissant.' Here too, we arguably find La Grange talking about gossip, with the chain of on dit's ironically mimicking the manner of its propagation; given La Grange's usual eloquence, indeed, it seems at least possible to read this strikingly ungainly formulation as expressing ambivalence towards the spread of these sordid rumours. Yet this entry is in another sense a paradigmatic example of gossip - and not despite, but even because of its being written in a private journal. We might call gossip a form of communication addressed by no one in particular to no one in particular, in which both sender and receiver participate for the intrinsic pleasure of the act, and are invested in the specific content of the message only to the extent that it appeals to their curiosity. Why note down this rumour about Custine 
in a private journal - if not that it is precisely the kind of knowledge whose repetition gives pleasure, and whose piquancy makes it worth communicating to that absent 'other' to whom we address our most intimate words? To talk about gossip, furthermore, is never entirely to refrain from gossiping. Gossip may even be indicatively 'metadiscursive': while one can imagine some originary act of gossip, where the gossip recounts what he has seen, the classic gossipy mode always involves repeating what one has been told. As La Grange's formulation suggests, gossip is the ever-increasing mise-en-abyme of confidential language.

Put differently, gossip is at once text and commentary, and the Olivier novels inhabit this double role with gleeful self-knowledge and to the furthest possible extent: though created as acts of gossip, their self-referentiality and relative complexity make them a meditation on gossip as well, which they depict now as a fact of the human condition, now as an acute affliction of Restoration high society. The final 'note' appended by Duras to her original novel places the idea of gossip in a particularly visible location - the final sentence:

On n'a jamais su le secret d'Olivier. Quelques personnes ont répandu dans le monde qu'il avait eu des raisons de se croire le frère de madame de Nangis. Cette conjecture a paru probable, mais elle est demeurée sans preuve comme toutes celles auxquelles cette déplorable aventure a donné lieu. ${ }^{23}$

While this note certainly appeals to the literary legitimacy of that epochal narrative of sexual concealment and disclosure, René, its purpose is probably not to posit an incestuous solution to Olivier's secret, but rather to underscore the status of that secret as the object of public speculation. From this cue, the subsequent Olivier novels elaborate a world in which gossip is tireless and ubiquitous; Latouche's Olivier calls it 'curiosité', speaking repetitively of 'la curiosité publique' in its preface, of the 'extrême curiosité' provoked by its hero's behaviour and 'la jalouse curiosité du public' attaching to all his activities, and of 'l'empressement curieux de la société' following his departure for a monastery at the denouement. ${ }^{24}$ 
Perhaps the most interesting such observation occurs towards the end of Latouche's novel, when Olivier lives briefly in chaste but unwed bliss with Émilie, who is recovering from a brain fever brought on by her would-be lover's vacillations. The eventual discovery of this irregular living arrangement by the ever-curious public is explained thus by the narrator: 'Il n'est rien de longtemps caché dans une société où la conversation est le principal emploi du temps. ${ }^{25}$ Though Latouche's Olivier is set under the Ancien Régime, this sentence is clearly intended as an indictment of the leisured classes of the Restoration, and of salon culture in particular. The accusation is hypocritical, of course, given the origin of Latouche's own source material - indeed, the leaking of Émilie's secrets here neatly allegorizes the unwanted diffusion of Mme de Duras's provocative literary subject. But the Olivier novels are surely right in their sense that the salon offers a special setting in which to explore the question of gossip; as Hammond notes, gossip takes on a 'peculiar intensity' - seeming, for better or worse, more important - in societies where conversation is particularly encouraged. ${ }^{26}$ While Mme de Genlis dwells sententiously on the 'inviolable fidélité' with which salon secrets must be kept, castigating the 'bavard' and the 'médisant' as a veritable social menace, the duchesse de Maillé freely admits that only 'des anecdotes scandaleuses' could vary the tedium of salon life. ${ }^{27}$ The salon moreover presented the novelists with an intriguing blurring of public and private communication. Certainly, some salons appear to have supported both conversation générale and particulière, ${ }^{28}$ yet since all private conversations in the salon happened in sight of other members, this very distinction gives rise in the novels to the constant risk of being overheard. This aspect of salon life in particular preoccupies Stendhal in Armance, whose subtitle, quelques scènes d'un salon de Paris en 1827, indicates how fundamental that setting is to his design. In this novel, characters within the salon frequently speak to $(\grave{a})$ a particular character, though their words are intended for (pour) some other person; they may baldly eavesdrop on private conversations (indeed, the 
best one may hope for in this regard is to speak 'sans être précisément entendu des voisins' (119)); they may communicate with each other through glances, while continuing their own separate conversations; and, in the advanced case of protagonists Armance and Octave, they may pursue a secret communication with each other while speaking to indifferent third parties: 'il s'établissait ainsi pour eux au milieu de la société [...] non pas une conversation particulière, mais comme une sorte d'écho qui, sans rien exprimer bien distinctement, semblait parler d'amitié parfaite et de sympathie sans bornes' (211).

In this example, public communication provides the opportunity for an ineffable private exchange - but that exquisitely fragile pleasure only lends poignancy to Stendhal's evocation of a world in which the space for true intimacy appears vanishingly small, and in which the most confidential exchanges are permanently at risk of publication. This is a vision that Custine himself appears quite understandably to have shared. In his own self-justifying novelization of the 1818 episode, Aloys (1829), we find a nightmarish scene in which the young hero's private letter to Mme de M.*** (who clearly corresponds to the duchesse de Duras) is produced by that esteemed lady before the members of her salon, and handed, naturally enough, to a visiting German graphologist for analysis. The private communication pursued in this otherwise public entertainment is both an insult - the hostess attempts to persuade the graphologist to pronounce the handwriting feminine and irresolute - and a threat, underscoring the power she has to destroy Aloys's reputation by leaking the contents of the letter into the public sphere. ${ }^{29}$ This scene is moreover emblematic of a phenomenon within the texts which may be characteristic of the period, namely, the extreme readiness of fictional and historical personages alike to share private correspondence with third parties. Chateaubriand, a protector of Custine, seems to have been in the habit of forwarding the young man's letters to his intimate friend Mme de Duras, and vice versa, in order to advance the marriage project of 1818; Custine's mother Delphine, meanwhile, would regularly send 
her son's correspondence on to Chateaubriand for analysis. ${ }^{30}$ All the Olivier novels incorporate such invasions of privacy, which may, as in these examples, be benign in intention if not necessarily in consequence. Yet Latouche's and Stendhal's novels, whose social vision is hostile to aristocratic society and thus more hyperbolic, seem ultimately to reimagine letters in aristocratic culture as serving principally as instruments of blackmail; to coerce another by threatening to leak private correspondence is, in Latouche's recurrent phrase, to 'faire usage' of letters which are thus reinvented as existing for just this purpose. In the world of Olivier, every private communication is thus a secret waiting to get out.

\section{Olivier in the Closet}

'By the end of the nineteenth century', Eve Kosofsky Sedgwick notes, 'it had become fully current - as obvious to Queen Victoria as to Freud - that knowledge meant sexual knowledge, and secrets sexual secrets. ${ }^{, 31}$ Mme de Duras seems herself to have grasped this idea as early as 1821 , and her gift to the culture is a novel which turns the imagined sexual pathology of a single individual - Astolphe de Custine - into an availing metaphor for all non-conforming sexuality: the secret. She makes the point most explicitly, of course, in that final note, where the narrator claims that the 'conjecture' of consanguinity remains unproven 'comme toutes celles auxquelles cette déplorable aventure a donné lieu' ${ }^{32}$ This, we now see, is a powerful literary device, at once preserving the broadest possible symbolic valence for the novel, and perceptively situating the sexual secret as an object of conjecture - that is, as the object of other people's curiosity. Indeed, the most interesting possibility suggested by the Olivier novels is that sexual identities or 'secrets' do not pre-exist social scrutiny, but are instead constructed by it; that such scrutiny seems in Olivier and Armance inevitably to conduce to blackmail, to the acquisition of 'des avantages sur' somebody or 'un moyen de perdre' somebody else, suggests just how invidious that process of construction might be. 
The sexual subject so constituted exists in a state of permanent crisis and threat, and it is in this light richly symbolic that the later Olivier novels respond to the events of 28 October 1824 - a primal scene to be sure, but one in which actual sex is entirely displaced by repressive violence.

While individual curiosity may be idle, moreover, the threat produced by collective curiosity in these novels operates to a purpose. Society, Stendhal's narrator tells us, 'avait autrefois le privilège de juger de ce qui est bien; mais depuis qu'elle se sent attaquée, elle condamne [...] ce qu'elle croit nuisible à ses intérêts' (124). Armance implies that the Restoration elite considered its 'intérêts' to lie in strategic marriages between its own members, and thus in the production of heirs - and indeed, the novel's composition in or around 1826 is contemporaneous with the Villèle government's abortive attempt to reintroduce limited primogeniture, widely denounced in liberal circles as the reinstatement of an Ancien Régime privilège. The plot also follows the approval in 1825 of the so-called milliard des émigrés, compensation for émigré aristocrats whose property had been confiscated during the Revolution. Octave's father regards this measure as a dynastic event: 'Ma chère amie,' he tells his wife on hearing the news, 'nous verrons nos petits-enfants avant que de mourir' (63), meaning (though considering it unnecessary to state explicitly) that Octave's wealth now matches his birth, so an advantageous, presumptively fertile marriage is once again in prospect. This intertwining of private family strategies with the political requirements of a monarchical regime was not, moreover, purely a figment of Stendhal's liberal imagination; as early as 1817 , the marquise de Montcalm mischievously observed that 'la pairie héréditaire a donné naissance à beaucoup d'enfants'. ${ }^{33}$ Under such political circumstances, we might suppose, the sexual conformity of socially well-placed young men becomes exposed to particular scrutiny, and their sexual non-conformity subject to the strictest possible censure. Indeed, while the anti-monarchist authors of Olivier and Armance 
may well mean to imply that 'when a group [...] begins to fail in its objective, gossip and scandal accelerate the process of disintegration', ${ }^{34}$ the novels can equally be seen to illustrate just how the coercive power of public opinion might act as a means of defending and reinforcing such powerful collective objectives. This is the power that speaks in the 'déchaînement universel' (239), the outburst of gossip and condemnation led by the furious 'grandes dames qui avaient des filles à marier', that greets the announcement of Octave's engagement to the socially inferior Armance; a fictional 'déchaînement' that is itself the literary echo of the real one that followed Custine's ill-fated outing of 1824. As the salonnière Mme Swetchine observed, in a metadiscursive - which is to say, gossipy - letter to La Grange describing society's reaction to Custine's humiliation: 'Jamais je n'ai vu un déchaînement si général. ${ }^{35}$

It should already be clear that this situation, in which moral, political and epistemophilic impulses converge to make of an individual's private sexual conduct the preeminent form of the secret, closely resembles the cultural structure known as the closet. Queer theory has indeed taught us to recognize an abiding blackmailability as characteristic of modern gay male sexuality, and the Olivier novels perhaps anticipate a Wildean or Proustian cultural arrangement in their recognition that the socially privileged male is particularly vulnerable to such pressures. ${ }^{36}$ In an influential reading of Armance from 1992, conceived in a gay-liberatory mode, Dominique Fernandez adduces precisely these implications of blackmail (alongside clichés including over-attachment to the mother and the tendency to suicide) as evidence that Octave's secret is, simply, his homosexuality. ${ }^{37}$ Yet the fact that the very same conclusion had already been reached in 1954 by the essayist Paul Morand in a decidedly homophobic account of the novel suggests that it might be historically and politically important to disalign the Olivier/Octave character and his proto-closet; to resist the soldering of a character and a predicament into a type - the homosexual - which 
can only naturalize the arbitrary and changing (though always extortionate) social ordering of sexual identities. ${ }^{38}$ Note that in developing their argument, both Fernandez and Morand ridicule the notion that Octave's secret is impotence - despite the famously bawdy letter from Stendhal to Mérimée suggesting precisely that - on historically dubious grounds. 'L'impuissance n'est pas un crime. L'impuissant n'est pas un monstre,' writes Morand; yet the evidence suggests that 'the impotent' could indeed be regarded as monstrous in the medical literature of the time, while 'impotence trials' (in the context of ecclesiastical annulment proceedings) had occurred within living memory of the Restoration. ${ }^{39}$ That Morand considers these terms self-evidently applicable to homosexuality and homosexuals, moreover, suggests the consistency of the language of sexual phobia even as its precise object shifts over time.

More importantly, however, Armance is not nearly as exclusively preoccupied with Octave's sexual proclivities as later critics have been. While the novel's obsessive use of the adjective singulier to describe Octave commonly triggers the critical gaydar, the application of the same adjective to Armance herself (at one moment, seven times in four pages) is surely equally remarkable (cf. 85-88, 223). Remarkable, too, that Armance should find herself as vulnerable to, and afraid of, gossip and blackmail as her reluctant fiancé. In one telling episode, Armance imagines the likely rage of the society ladies were she to be so impudent as to wed their darling, Octave:

J'entends d'ici ce que dirait madame la duchesse d'Ancre et même les femmes les plus respectables [...]. La perte de ma réputation serait d'autant plus rapide, que j'ai vécu dans l'intimité de plusieurs des femmes les plus accréditées de Paris. (138)

Armance supposes that those who have enjoyed the most privileged social access and consideration are subject to the severest reprisals if they fail in their social duties, and the theory is not hers alone. In her letter to La Grange, Mme Swetchine observed that Custine's 
dishonour had left 'la société en masse [...] en colère, comme on le serait d'une perfidie personnelle ; on lui demande compte surtout de l'estime qu'on avait pour lui' ${ }^{40}$ The punitive calculus applied to Custine in 1824, then, is in Stendhal's novel displaced onto the heroine's conduct. Armance dreads being denounced by lettres anonymes just as much as her dilatory lover $(125,139)$; she is just as at risk of becoming the butt of some 'histoire fâcheuse' as he is (205); she too possesses her 'fatal secret' (104) in the form of her undeclared love for him. And it is she, finally, who must conceal her love life 'in the closet': having rashly decided to make an improper night-time visit to Octave in his bedroom, she repents and ducks into an adjacent 'petit cabinet' to avoid being seen by him - only to emerge too soon and be spotted on the landing by Octave's malevolent uncle (228-29). From this point on, the two protagonists are united in their peril: the uncle now has 'un moyen de les perdre à jamais' (230) by spreading word of Armance's nocturnal wanderings, and it is in order to neutralize this threat that Octave reluctantly announces their marriage. If Octave is in the closet, it is at the very least a closet he shares with Armance.

Now it might be objected that it is precisely this shared vulnerability that provides the surest evidence of Octave's sexual peculiarity: Octave, that is, is a male protagonist whose sexual conduct becomes subject to the merciless scrutiny and censure that the nineteenth century typically applied only to women. He is a man who finds himself, so to speak, on the wrong side of the sexual double standard. In fact, there is little doubt that this is part of Stendhal's agenda in Armance. Yet that argument hardly precludes the possibility that the novel and its predecessors also evoke a more generally oppressive imbrication of sexuality and gossip. To be sure, the Olivier figure emerges as indicative of some pathology and therefore as an object of special attention - though even here, the carefully preserved secrecy of that pathology makes it impossible to reduce Olivier to a single, stable 'type'. Yet the pervasive paranoia witnessed in both Latouche's and Stendhal's novels, in which every 
character is perpetually subject to the threat of sexual exposure and humiliation, suggests something more: that the discursive crucifixion of sexual 'deviance' requires and emerges from an unprecedented scrutiny of all sex and all sexualities. The secret of the Olivier novels is thus, we might say, a metaphor for sexuality per se; to these singular emanations of the Restoration imagination, modern sexuality is a universal closet.

\section{Conclusion}

So what is wrong with Olivier? For texts so obsessed with (and actively engaged in) the invasion of privacy, the Olivier novels keep their central secret most scrupulously, and not for nothing. These, as we have seen, are texts that value the 'deniability' that characterizes literary connotation; affirming nothing, they risk nothing. ${ }^{41}$ But the role of omission in the Olivier novels is more than one of mere self-protection: the rhetorical power of this device was well understood by writers like Stendhal and Latouche, who cut their teeth in the world of Restoration publishing - a world where, as Jacques Dürrenmatt notes, 'dire sans dire' was a necessary skill, and where blanks (indicating censored material) could be so subversive that the government found it necessary, in 1827 , to ban their use in newspapers. ${ }^{42}$ In truth, these novelists understand reticence to be a vital source of literary pleasure, forcing complicity and flattering the reader's sense of initiation. Are the Olivier novels about Astolphe de Custine's homosexuality? Who is to say so, since his name appears nowhere in any of them? Are they about impotence? We have only intercepted private communication (Mme de Duras's words 'en famille', Stendhal's letter to Mérimée) to suggest it. Gossip, I have said, is at once text and commentary; and any commentary on such duplicitous material surely risks becoming gossip itself, especially when it presumes - as I have here - to name names, to supply the very clé that Stendhal insists his own text does not require. There is, one fears, no extricating critical discourse from this double bind of coyness and prurience; in recovering the queer 
past, we will often be dependent upon the clues afforded by gossip. We can only hope that our motives are better.

\section{NOTES}

I should like to thank David Powell and Marco Wan for their invaluable comments on earlier versions of this article.

${ }^{1}$ Mme de Genlis, Mémoires inédits de Madame la comtesse de Genlis, 8 vols (Paris: Ladvocat, 1825), VI, 163.

${ }^{2}$ See Albert de Luppé, Astolphe de Custine (Paris: Éditions du Rocher, 1957), pp. 96-101; Olivier Gassouin, Le Marquis de Custine: le courage d'être soi-même (Paris: Lumière et Justice, 1987), pp. 37-40; and George Rousseau and Caroline Warman, 'Made from the Stuff of Saints: Chateaubriand's René and Custine's Search for a Homosexual Identity', GLQ, 7 (2001), 1-29 (pp. 2-3). For a recent summary of the episode, see Marie-Bénédicte Diethelm, 'La Boue de Saint-Denis (1824): Astolphe de Custine, "un homme marqué du sceau de la réprobation"”, Romantisme, 159 (2013), 47-58 (pp. 48-52).

3 James Creech, Closet Writing/Gay Reading: The Case of Melville's 'Pierre' (Chicago: University of Chicago Press, 1994)), pp. 19-25.

${ }^{4}$ Max Gluckman, 'Gossip and Scandal', Current Anthropology, 4 (1969), 307-316 (p. 308).

${ }^{5}$ See Julien-Frédéric Tarn, Le Marquis de Custine (Paris: Fayard, 1985), pp. 87-91.

${ }^{6}$ Astolphe de Custine, Lettres à Varnhagen d'Ense (Geneva: Slatkine Reprints, 1979), p. 255.

${ }^{7}$ Cited in Luppé, p. 69.

${ }^{8}$ Stendhal, Euvres intimes, ed. by V. Del Litto, 2 vols (Paris: Gallimard, 1982), II, 446.

${ }^{9}$ Duchesse de Maillé, Souvenirs des deux Restaurations (Paris: Perrin, 1984), p. 153; comtesse de Boigne, Mémoires de la comtesse de Boigne, 2 vols (Paris: Mercure de France, 1971), I, 475. 
${ }^{10}$ See for instance Maillé, p. 84.

${ }^{11}$ Contemporaneous medical literature on impotence supports this notion: see for instance P. Maur, Essai sur les causes de l'impuissance et de la stérilité (Paris: Didot jeune, 1805); and Michel-Étienne Descourtilz, Propositions sur l'anaphrodisie (Paris: Didot le jeune, 1814).

12 Tarn, p. 80 .

${ }^{13}$ Maillé, p. 232.

${ }^{14}$ Stendhal, Armance, ou quelques scènes d'un salon de Paris en 1827 (Paris: Flammarion, 1994), p. 47. Subsequent references are given in the text.

${ }^{15}$ See Journal des débats, 24 January 1826; similar repudiations appeared in La Quotidienne on the same day and the Moniteur universel on 25 January.

${ }^{16}$ See La Quotidienne, 28 January 1826.

${ }^{17}$ See Deborah Jenson, Trauma and its Representations: The Social Life of Mimesis in PostRevolutionary France (Baltimore: The Johns Hopkins University Press, 2001), pp. 126-39; and Margaret Waller, The Male Malady: Fictions of Impotence in the French Romantic Novel (New Brunswick: Rutgers University Press, 1993), pp. 114-35.

${ }^{18}$ Henri de Latouche, Olivier (Paris: Société des médecins bibliophiles, 1924), p. 11.

${ }^{19}$ See Stephen Kale, French Salons: High Society and Political Sociability from the Old Regime to the Revolution of 1848 (Baltimore: Johns Hopkins University Press, 2004), ch. 5. ${ }^{20}$ See Gassouin, pp. 37-40.

${ }^{21}$ See Journal des Débats, La Quotidienne and Le Moniteur universel, 7-11 November 1824.

${ }^{22}$ See Nicholas Hammond, Gossip, Sexuality and Scandal in France (1610-1715) (Bern: Peter Lang, 2011), p. 17 (citing James C. Scott); and Gluckman, p. 308 (citing Melville J. Herskovits). 
${ }^{23}$ Mme de Duras, Ourika. Édouard. Olivier ou le secret, ed. by Marie-Bénédicte Diethelm (Paris: Gallimard, 2007), pp. 304-05.

${ }^{24}$ Latouche, pp. 12, 17, 69, 94.

${ }^{25}$ Latouche, p. 69.

${ }^{26}$ Hammond, p. 7.

${ }^{27}$ Genlis, III, 279-80; Maillé, p. 238.

${ }^{28}$ See Anne Matin-Fugier, La Vie élégante ou la formation du Tout-Paris, 1815-1848 (Paris: Perrin, 2011), pp. 217-20.

${ }^{29}$ Astolphe de Custine, Aloys, ou le religieux du mont Sain-Bernard (Paris: Fontaine, 1983), pp. 141-43.

${ }^{30}$ See Tarn, p. 121.

${ }^{31}$ Eve Kosofsky Sedgwick, Epistemology of the Closet (Berkeley: University of California Press, 2008), p. 73. In light of this association, I regard Olivier's 'secret' as connoting, in some irreducible historical way, the sexual; that is, I believe most Restoration readers would intuitively have understood it thus. But for readings of Armance adopting other approaches, see for instance Shoshana Felman, La 'folie' dans l'œuvre romanesque de Stendhal (Paris: Jose Corti, 1971); Pierre Barbéris, 'Armance, Armance, quelle impuissance?', in Stendhal: Colloque de Cérisy-la-Salle, ed. by Philippe Berthier (Paris: Aux amateurs des livres, 1984), pp. 67-85; Pierre Bayard, Symptôme de Stendhal: Armance et l'aveu (Paris: Lettres modernes, 1979); and Régine Borderie, 'Structures et figures du secret dans Armance', Poétique, 93 (1993), 77-90. For perhaps the fullest investigation of the theme, see Georges Kliebenstein, Enquête en Armancie (Grenoble: Ellu, 2005).

${ }^{32}$ Duras, p. 305.

${ }^{33}$ Marquise de Montcalm, Mon journal (Paris: Honoré Champion, 2012), p. 297.

${ }^{34}$ Gluckman, p. 314. 
${ }^{35}$ Madame de Swetchine, Nouvelles Lettres au marquis de La Grange (Paris: Amyot, 1875), p. 78 (30 July 1825).

${ }^{36}$ See Eve Kosofsky Sedgwick, Between Men: English Literature and Male Homosocial Desire (New York: Columbia University Press, 1985), p. 90.

37 See Stendhal, Armance, ou quelques scènes d'un salon de Paris en 1827, preface by Dominique Fernandez (Paris: P.O.L., 1992), pp. i-xxi.

${ }^{38}$ See Paul Morand, L'Eau sous les ponts (Paris: Grasset, 1954), pp. 75-76.

${ }^{39}$ Morand, pp. 74-75. On impotence trials, see Pierre Darmon, Le Tribunal de l'impuissance (Paris: Seuil, 1986).

${ }^{40}$ Swetchine, p. 78.

${ }^{41}$ D. A. Miller, "Anal Rope", in Inside/Out: Lesbian Theories, Gay Theories, ed. by Diana Fuss (New York: Routledge, 1991), p. 124.

42 Jacques Dürrenmatt, 'Allusion et obscurité: violence et langage dans les chroniques stendhaliennes', in Stendhal, journaliste anglais, ed. by Philippe Berthier and Pierre Louis Rey (Paris: Presses de la Sorbonne Nouvelle, 2001), pp. 213-26 (p. 214). On blanks in the press, see Boigne, II, 85 . 